\title{
Dakwah Keluarga: Internalisasi Nilai- nilai Budi Pekerti dalam Keluarga Jawa
}

\author{
Nawawi \\ STAIN Purwokerto \\ E-mail: nawawi71@ymail.com
}

\begin{abstract}
This study focused on the system of social organization, the internalization process in the family, phases of the internalization, values are internalized Java manners and internalization models used. The purpose of this study to determine the implementation process of internalization, its phases, values and manners Java internalization models used. The research was conducted in three families in Bonjokmangir Java. The interpretive techniques used to analyze the values contained in the manners of the three families of Java. This study uncovered three families in the internalization process Bonjokmangir, values and manners Java internalization models used. Character values include the principles of Java respectful, harmonious life, honesty, introspection, sincere and selfless, mindful character, manners, ngati-ati, nrima and resigned. Internalization stage there are three phases namely the unborn baby through childhood, during adolescence and adulthood period. Internalization models used a model of democracy, exemplary models, wayang model fitting and communication model using the Java language and manners in the family associate.
\end{abstract}

\section{Kata kunci:}

Internalisas nilai, Budi Pekerti, Keluarga Jawa.

\section{A. Pendahuluan}

Arus globalisasi, tuntutan era komunikasi, perkembangan ilmu pengetahuan dan teknologi ternyata besar pengaruhnya terhadap sikap, 
cara hidup dan pola pikir manusia. Rekayasa kultural besar-besaran lambat laun juga menjadi pil pahit terhadap sendi-sendi budi pekerti bangsa. Sekat-sekat budi pekerti yang kaya akan nilai-nilai budaya jawa yang luhur kian pudar karena sentuhan-sentuhan kemanusiaan antarbangsa. Akibatnya sulit dipungkiri bahwasanya generasi muda sekarang dianggap sudah tidak njawani lagi. Penilaian ini muncul, sebagian didasarkan pada sikap dan perilaku negatif yang mereka perlihatkan sehari-hari yang sudah semakin jauh meninggalkan nilainilai budi pekerti. Anak-anak yang semula polos dan lugu, sekarang telah terjangkiti erosi akhlak dan kemunduran moral.

Koentjaraningrat (1984: 443) mengemukakan bahwa orang Jawa sekarang telah terpengaruh nilai-nilai budaya barat yang dapat merusak nilai-nilai budaya tradisi Jawa yang ada. Hal ini ditandai oleh berbagai perubahan besar-besaran pada poros dan akar budaya Jawa. Sikap hidup Jawa yang merupakan wajah esensial budaya Jawa, kini sedang larut ke dalam zaman edan, yang antara lain bercirikan keteraturan terganggu, keadilan menipis, ekonomi sulit dan tata nilai yang saling berbenturan.

Sikap-sikap yang berbau kekerasan dan kebrutalan mulai merambah di dunia pendidikan. Tawuran antarpelajar yang berbuntut kekerasan fisik, juga merupakan fenomena kemerosotan budi pekerti. Tindakan-tindakan asusila baik yang dilakukan oleh murid dengan sesama murid maupun guru dengan muridnya atau sesama guru, juga menjadi potret buram budi pekerti. Belum lagi ditambah kehidupan keluarga yang ditandai oleh perilaku anak-anak yang mulai sekecap padha sekecap berani membantah dengan orang tuanya. Anak mulai tumbuh "keberanian" yang lepas kendali kepada orang tua, sebagai pengaruh dari era komunikasi publik terpampang di depan mata.

Semua tindakan yang kurang kontrol etika ini mencerminkan bahwa dalam kehidupan telah terjadi erosi moralitas yang semakin menjadi-jadi. Tentu saja sebagai sebuah peristiwa erosi tentu ada obat dan cara pencegahannya. Aspek preventif budi pekerti tentu lebih efektif dibanding aspek kuratif. Namun melihat gejala erosi yang sudah merambah dalam segala wacana kehidupan, kiranya obat mujarab pun perlu segera ditemukan agar budi pekerti luhur ini tidak terlanjur terinfeksi. 
Etika dan tatakrama dalam pergaulan masa kini menurut Supadjar (1985: 185) telah dipenuhi gelombang permasalahan berkat jaringan komunikasi dan jalinan secara mondial. Etika dan tatakrama adalah bagian penting dari pendidikan budi pekerti. Oleh karena itu jika etika dan tatakarama telah terpengaruh oleh riak gelombang zaman, berarti budi pekerti juga semakin jauh menggelincir jauh dari harapan. Dengan kata lain, sulit terelakkan bahwa globalisasi dan multidimensional telah memberi warna tersendiri dalam membentuk watak bangsa. Pesatnya perkembangan teknologi dan media informasi telah menyebabkan budi pekerti luhur bangsa ini terdesak dan terkikis. Situasi bangsa yang semakin modern, merebaknya budaya instan dan masyarakat konsumtif telah memberikan aroma budi pekerti masyarakat masa kini.

Benturan-benturan kultural dengan berbagai bangsa di belahan dunia, juga telah memoles budi pekerti bangsa Indonesia menjadi tidak murni. Budi pekerti yang semula merupakan salah satu pilar jati diri bangsa sedikit demi sedikit terbawa erosi zaman. Semua tindakan yang kurang terkontrol oleh etika tersebut mencerminkan bahwa dalam kehidupan telah terjadi erosi moralitas. Jika hal ini dibiarkan sehingga menyentuh sendi-sendi watak bangsa tentu akan berakibat fatal. Paling tidak akan terjadi perubahan masyarakat beradab menjadi biadab, masyarakat berbudaya menjadi masyarakat tak berbudaya, masyarakat berbudi pekerti menjadi buta budi pekerti. Jika kemungkinan terakhir ini terjadi berarti penyakit kronis telah menggerogoti urat nadi budi pekerti. Itulah sebabnya aspek kuratif dan prefentif melalui penanaman budi pekerti sejak usia dini jauh lebih penting, sebelum degradasi moral menjalar pada usia remaja atau dewasa.

Dengan demikian, keluarga mempunyai peranan penting dalam pendidikan dan internalisasi nilai-nilai pada anak di dalam keluarga. Hal ini merupakan konsekuensi logis dari fungsi keluarga dalam kaitan dengan keberadaan dan status anak. Orang tua dan anak sebagai komponen sistem utama keluarga merupakan suatu kesatuan dalam mencapai tujuan keluarga. Ditengah perubahan yang terjadi dalam kehidupan masyarakat, dan derasnya erosi budi pekerti, ada beberapa keluarga di Desa Bonjokmangir yang berusaha membendung aliran informasi dan modernitas dengan melakukan internalisasi nilai-nilai budi pekerti pada keluarganya. Inilah yang menarik perhatian saya untuk mengetahui lebih jauh bagaimana proses pelaksanaan 
internalisasi dalam tiga keluarga tersebut, nilai-nilai budi pekerti yang bagaimana yang akan diinternalisasikan dan menggunakan modelmodel seperti apa dalam pelaksanaan internalisasi.

\section{B. Rekontruksi Etika Dalam Keluarga Jawa}

\section{Menanamkan Prinsip Hormat}

Prinsip hormat termasuk kaidah sosial yang berperan dalam interaksi masyarakat Jawa. Prinsip hormat merupakan kaidah sosial untuk menjaga keselarasan hubungan antar anggota masyarakat. Implikasi sikap hormat akan terkait dengan budi pekerti yang menyangkut unggah-ungguh dan tatakrama Jawa. Prinsip hormat ini pertama-tama akan dipelajari anak dalam keluarga. Hubungan anak dengan orang tua secara tidak langsung juga akan mencerminkan aplikasi prinsip hormat.

Menurut Muhsinun anak-anak Jawa belajar prinsip hormat melalui tiga situasi, yaitu sikap: wedi, isin, dan sungkan. Ketiga situasi ini merupakan suatu kesinambungan perasaan yang mempunyai fungsi sosial untuk memberi dukungan psikologis terhadap tuntutan prinsip hormat. Sikap ini merupakan cermin budi pekerti yang dapat dipelajari anak melalui komunikasi dalam keluarga. Dalam keluarga akan terjadi kontak selalu terkait dengan budi pekerti. Hubungan antara suami isteri, ayah dengan anak laki-laki, dan hubungan keluarga inti dengan keluarga lain banyak memberi manfaat dalam belajar budi pekerti.

Budi pekerti yang terkait dengan sikap hormat, dilakukan oleh anak kepada orang tuanya baru kepada orang lain di luar keluarga. Sarino Mengatakan "sikap hormat kepada orang tua terdorong oleh ungkapan wong tuwa ala-ala ngualati”, maksudnya kendati jelek, orang tua itu bertuah. Akibat yang dapat menimpa dari sikap dan tindakan tidak menghormati orang tua ialah akan kuwalat. Mungkin orang tua itu jelek dan sudah tidak dapat berbuat apa-apa, namun seorang anak tetap berpegang bahwa ila-ila ujare wong tua. Maksudnya apa yang dikatakan orang tua akan bertuah karena telah didasari pengalaman panjang. Lebih lanjut Sarino mengatakan "wong tua nek ora aweh uwur ya sembur". Orang tua kalau tidak memberi bekal harta, dia akan memberi bekal petuah. Orang tua mempunyai banyak pengalaman dalam hidupnya, artinya pahit getirnya hidup sudah banyak dialami. 
Oleh karena itu apa yang berikan berupa materi disebut uwur (akan menjadi bekal hidup) dan pesan yang dinasehatkan disebut sembur (doa). Bagi orang tua pesan dan nasihat yang telah dipatuhi dan diperhatikan untuk dilaksanakan kepada anak-anaknya merupakan suatu kebahagiaan yang tiada taranya. Atas dasar sikap hormat tersebut, anak harus berbakti dan menghormati orang tuanya. Anak harus dapat nyuargaake wong tuwa (membawa ke surga). Anak harus berbuat baik untuk orang tuanya, lebih-lebih mendoakan. Berbagai cara dapat ditempuh untuk membahagiakan orang tua.

Sikap hormat seseorang kepada orang lain di luar keluarga, dilakukan sebagai langkah menuju keselarasan sosial. Sikap saling hormat-menghormati dalam segala aspek kehidupan, akan mampu menjaga keutuhan sosial. Sikap hormat merupakan bentuk penghargaan seseorang kepada orang lain melalui tutur kata dan tindakan. Karena itu, jika seseorang ingin kajen (terhormat) di masyarakat juga harus mau menghormati orang lain.(Handayani dan Novianto: 2004, 12).

Sikap hormat yang "murni", mestinya tidak harus terbentuk atas paksaan atau dipaksakan karena status atau struktur sosial. Sikap hormat bukan lahir dari rasa takut atau sebuah kewajiban struktural. Sikap hormat-menghormati harus lahir dari kedua belah pihak. Misalnya, seorang bawahan harus hormat kepada atasan, begitu pula sebaliknya sang atasan juga harus menghormati bawahan.

\section{Menanamkan Hidup Rukun}

Rukun merupakan ukuran ideal bagi hubungan sosial. Rukun berarti keadaan yang serasi, penuh kerja sama, gotong royong, dan peniadaan perselisihan sebaik-baiknya. Prinsip hidup rukun sebenarnya terdorong oleh ungkapan tradisional crah gawe bubrah rukun agawe santosa berarti bahwa pertengkaran akan membuat kerusakan, dan rukun akan mernbuat persatuan semakin kuat.

Dalam pergaulan sosial, anak-anak sudah belajar hidup rukun sejak dini, setidaknya rnulai dalam keluarga. Antar sesama anggota keluarga telah ditanamkan agar jangan bersikap cecengilan iku ngedohake rejeki. Pertengkaran sesama saudara siapa pun akan mengakibatkan anugerah rejeki semakin jauh. Nilai kerukunan ini, selanjutnya akan diperlebar lagi dalam pergaulan masyarakat. Dalam 
hal ini orang Jawa seperti yang dikatakan Sarino harus berprinsip aja nganti kepaten pasaban. Maksudnya, jangan sampai kehilangan tempat bergaul. Manusia adalah makhluk sosial, karena itu agar tercipta kerukunan harus selalu melakukan silaturahmi.

Lebih lanjut dia mengatakan "Dalam bergaul, diharuskan bersikap luwih becik kalah uwang tinimbang kalah uwong". Artinya, lebih baik merelakan uang, daripada harus berselisih dengan tetangga. Istilah yang senada dengan ini adalah tuna satak bathi sanak. Ungkapan ini menyadarkan kepada seseorang bahwa harta benda yang melimpah, tidaklah ada artinya bila orang harus kehilangan martabat sebagai manusia. Nilai manusia lebih tinggi daripada nilai benda. Para leluhur juga telah mengajarkan agar bersikap rukun melalui sebuah lagu sebagai berikut:

\section{Enthik enthik patenana si panunggul}

gek dosane apa,

dosane ngungkul-ungkuli,

dhi aja dhi malati sedulur tuwa (Simon, 2008: 313).

(Enthik-enthik bunuhlah si panunggul

Sedangkan dosanya saja apa

Dosanya selalu mengungguli

Dik jangan dik saudara tua akan malati)

Lelagon (tembang) tersebut sering ditembangkan sebagai pupuh pocung. Isinya menggambarkan agar hidup rukun dengan anggota keluarga. Hidup dalam keluarga, ibarat jari-jari lima (jempol, panuduh, panunggul, jenthik manis, dan jenthik ragil. Dari lagu tersebut, tampak bahwa jari tengah oleh jari kelingking dianggap mengunggulinya. Karena itu, kelingking berusaha untuk membunuh jari tengah. Hal ini sekaligus merepresentasikan sikap keirihatian dalam sebuah keluarga. Dari lagu itu juga tersugestikan agar hidup berkeluarga didasarkan saling rukun, saling berbuat baik dengan saudara dan saudara muda atau kecil juga harus menghormati kepada saudara tua. Kekurangan dan kelebihan di antara anggota keluarga, semestinya tidak dibesarbesarkan. Apalagi, mereka hanya saudara sepupu yang kadang-kadang tinggal satu rumah, jika terjadi perselisihan tentu akan berantakan.

Prinsip kerukunan, juga akan membuat hidup manusia tenteram dan sederhana. Hidup akan lebih tenang, tidak iri hati dengan saudara, 
dan akhirnya bersikap apa adanya. Hal ini seperti terungkap pada lagu dolanan Tahu Tempe sebagai berikut:

Tahu-tahu tempe tahu-tahu tempe,

asale mung saka dhele,

nadyan barang sepele,

nanging nyata enak rasane,

kabeh-kabeh mbutuhake,

jalaran murah regane

blanja sithik bisa sampe,

ora butuh kae-kae waton cukup ben dinane,

pokok rukun sakluwargane,

tahu-tahu tempe tahu-tahu tempe (Purwadi, 2004: 101)

\section{Menanamkan Sifat Jujur}

Setiap orang tua berusaha menanamkan sifat jujur kepada anakanaknya. Sebab, ada pepatah yen ora jujur ajur, artinya jika tidak jujur bakal hancur nasibnya, Kejujuran, termasuk nilai moral Jawa yang amat tinggi, Dalam cerita anak-anak (dongeng) berjudul Jujur, dilukiskan tindakan jujur sebagai berikut:

"Nik, wong urip ing alam donya iki kudu laku jujur lan tansah nandur kabecikan tumrap sapepadha." Kaya ana daya magnit, Nunik mlaku tanpa mikir sepatune sing rusak. Tujuane mung siji, menyang daleme bu Yuni, mbalekake dhompet iku marang sing kagungan. (Mugiayarto dan Prastiyo, 2008: 31).

(Nik, orang hidup di dunia ini harus bersikap jujur dan selalu menanamkan kebaikan terhadap sesama. Seperti ada daya magnit. Nunik berjalan tanpa memikir sepatunya yang rusak, tujuannya hanya satu, ke rumah $\mathrm{Bu}$ Yuni dan mengembalikan dompet itu kepada pemiliknya).

Sikap jujur yang ditunjukkan tokoh Nunik di atas pantas dipuji. la tetap ingin mengembalikan dompet yang ditemukan, meskipun kondisi sepatunya rusak. Padahal, kalau dia tidak jujur, dompet yang berisi uang itu dapat berkeluarga. Kejujuran anak terhadap orang tua, misalkan jika ada uang tergeletak di meja, apakah si anak akan mengambilnya atau tidak. Hal ini merupakan ujian budi pekerti yang menyangkut kejujuran. Kejujuran dalam keluarga akan menjadi modal 
tidal untuk hidup bermasyarakat yang lebih luas. Aris menceritakan, uang di laci tokonya tak pernah dikunci, tapi anak-anaknya tak pernah mengambil tanpa seijin ibu atau bapaknya, kalau mau mengambil nembung (minta izin) terlebih dahulu. Begitu pula bila mau mengambil jajanan bilang dulu pada siapa yang ada di toko (bapak atau ibunya), walaupun itu milik sendiri. Demikian pula Sarino, kadang-kadang menaruh dompetnya di sembarang tempat walaupun ada uangnya. Tetapi anak-anaknya tak ada yang berani mengambil uang dari dompetnya, kecuali atas izinnya.

Sikap jujur tersebut dalam tradisi budaya Jawa dilandasi oleh peribahasa 'becik ketitik ala ketara'. Artinya, perbuatan baik pasti akan kelihatan hasilnya dan begitu pula perbuatan salah akan ada akibatnya. Baik atau buruk kelakuan seseorang, akhirnya akan ketahuan. Setiap perbuatan buruk bagaimanapun usaha orang menutup-nutupi, pada akhirnya akan ketahuan juga. Sebaliknya perbuatan baik, meski tidak disebarluaskan pada akhirnya akan diketahui oleh orang banyak. Orang Jawa selalu mementingkan kejujuran dalam segala hal. Atas dasar prinsip tersebut mereka akan bertindak jujur dalam melakukan pekerjaan, dalam usaha, dalam perjuangan dan sebagainya. Apalagi ada ungkapan yang mengingatkan kejiwaan seseorang ketika akan bertindak, yaitu wong salah seleh. Artinya, orang yang berbuat salah akan kalah juga pada akhirnya. Siapa yang bersalah, orang yang menyimpang dari peraturan yang berlaku, orang yang merugikan orang lain, dan sebagainya akan merasakan akibat perbuatannya, akan ngunduh wohing pakarti (memetik hasil perbuatannya yang tidak baik). Karena itu dalam masyarakat Jawa juga dikenal ungkapan sing jujur mujur (orang yang jujur akan beruntung).

Dengan kata lain, jika dalam bertindak manusia sudah takut pada hukum karmapala, yakni sapa nandur ngundhuh atau sapa gawe nganggo (Mugiyarto dan Prastiyo, 2004: 97) sebenarnya tidak akan sampai hati kalau berbuat tidak jujur. Siapa yang berbuat salah akan mendapatkan akibat yang tidak baik, dan sebaliknya. Ungkapan ini mengandung nilai budi pekerti ke arah sikap hati-hati dalam bergaul di masyarakat. Janganlah berbuat seenaknya terhadap orang lain, sebab semua perbuatan pasti ada balasannya. Kesadaran bahwa perbuatan jelek akan kalah dengan perbuatan baik. Dalam ungkapan Jawa sering disebut suradira jayaningrat lebur dening pangastuti. Tindakan yang 
salah, tindakan yang jelek dan tidak jujur, akan kalah dengan perbuatan jujur yang disertai taat kepada Tuhan.

\section{Pembentukan Akhlak Sopan Santun}

Jika seseorang ingin berhasil, sukses, gemilang dalam bergaul hendaknya dapat bersikap anoraga (rendah hati) kepada orang lain. Dalam pergaulan sosial, seseorang hendaknya dapat membawa diri dan tidak membanggakan diri, melainkan harus anoraga. Sikap yang mengandalkan ungkapan sapa sira sapa insun lalu bersikap merendahkan dan meremehkan orang lain. Padahal, setiap orang memiliki kelemahan dan kekuatan.

Sikap seseorang yang mentang-mentang sedang berkuasa (dumeh kuwasa) sering terjadi di masyarakat. Biasanya, mereka itu terlalu membusungkan dada dan teriak-teriak, lalu bersikap adigang, adigung, adiguna sifat sombong yang mengandalkan kekuatan, kekuasaan, dan kepandaian (Herusatoto, 2003: 81). Karena itu, dalam segala bentuk kegiatan hidup, kemudian senang golek menange dhewe (mencari kemenangan sendiri). Sementara pihak lain harus kalah atau dikalahkan dengan berbagai cara. Orang yang bertindak semacam itu, terjebak pada ungkapan asu gedhe menang kerahe. Artinya, orang besar merasa harus menang dalam segala urusan. Mereka lalu bertindak sewenang-wenang kepada pihak lain. Mungkin, kalau orang lain dapat terhukum padahal hanya kesalahan sepele, sebaliknya mereka yang memiliki kesalahan bertumpuk-tumpuk dapat bebas dari dakwaan.

Sebenarnya manusia telah diingatkan agar aja mung golek wah. Maksudnya, manusia sebaiknya jangan mencari pujian karena gebyar dunia yang sesaat, atau bersikaplah sederhana (prasaja). Jangan gila terhadap sanjungan orang lain. Jangan mabuk pujian, karena manusia akan mudah lupa terhadap segala sesuatu, terhadap dirinya, dan lupa kepada Tuhan. Bahkan sering berlanjut pada sikap yang tidak berhatihati dan menghalalkan segala cara untuk memperoleh pujian. Jika ini terjadi, maka manusia akan gelap mata, lupa daratan, dan orang lain dapat menjadi korban.

Muhsinun menganalogikan sikap anoraga akan tampak seperti halnya eksistensi buah kelapa dan semangka. Buah kelapa, sebagai simbol orang yang tinggi hati. la merasa sombong, karena pohonnya 
tinggi, buahnya keras. Akibatnya pada saat memetik juga dipangkas, dijatuhkan (kadang-kadang hanya diletakkan di tempat yang kotor), dislumbat (dikuliti secara paksa), dipukul tengkoraknya, dicukil, diparut, dan masih diremas-remas. Kalau itu seorang manusia, nasibnya jelas celaka tujuh keliling. Berbeda dengan semangka, meskipun pohonnya lemah, ketika memetik terhormat, dipetik dengan pelanpelan, diletakkan pada mobil misalnya, dicuci, dan ditempatkan di piring yang bagus. Bahkan untuk konsumsi di tempat-tempat khusus. Ini simbol bahwa orang yang bersikap anoraga, akhirnya mendapatkan tempat yang mulia.

\section{Membentuk Watak Eling}

Ungkapan Pangeran iku ora sore kata Sarino, terkandung pesan bahwa manusia harus bersikap selalu ingat kepada Tuhan. Hidupnya selalu diawasi oleh Tuhan, karena itu harus berbuat baik. la juga menyatakan Pangeran iku cedhak tanpa senggolan adoh tanpa wangenan. Maksudnya bahwa hidup manusia selalu dekat dan diawasi oleh Tuhan. Mereka selalu yakin bahwa Tuhan itu tan kena kinaya ngapa (tidak bisa diperbandingkan dengan apapun). Budi pekerti semacam ini merujuk sikap hidup manusia Jawa yang selalu ingat kepada Tuhan. Dengan ingat Tuhan, manusia akan senantiasa berbuat kebajikan.

Ungkapan demikian juga meningkatkan keyakinan kepada setiap orang, bahwa Tuhan Maha Tahu. Tuhan mengetahui apa yang dilakukan oleh setiap manusia, apa yang dikatakan, bahkan apa yang dianganangankan, kapan saja, di mana saja. Tuhan mengetahui perbuatan baik atau buruk setiap manusia karena segala yang terjadi di seluruh alam ini diketahui oleh Tuhan, manusia akan membatasi diri dalam segala sikap dan perbuatannya dan selalu berbuat kebajikan. Manusia akan selalu berbuat baik karena dilandasi sikap eling bahwa wong urip mung mampir ngombe yang artinya hidup manusia itu tidak berlangsung lama, hanya sementara. Besok akan ada hidup lagi yang lebih kekal. Sedangkan hidup di dunia ini, hanyalah seperti orang singgah minum saja. Hidup yang tidak berlangsung lama itu diisi dengan perbuatanperbuatan yang baik bagi sesama, supaya kalau hidup sudah berakhir atau kematian sudah sampai, orang tidak menyesal. Dengan kata lain, 
ungkapan tersebut merupakan peringatan bagi semua orang, bahwa hidup di dunia hanya singkat karena itu hidup harus diisi dengan kegiatan-kegiatan yang dapat memuliakan nama Tuhan dan mendatangkan kesejahteraan bagi orang lain. Lebih tajam lagi, manusia selalu ingat akan mati dan harus beramal baik sebagai bekal hidup nanti.

Manusia harus senantiasa eling terhadap sangkan paraning dumadi. Maksudnya, harus selalu ingat asal-usulnya, jangan sampai lali maring asale (lupa akan asalnya). Manusia berasal dari Tuhan, kelak juga akan kembali kepada-Nya. Dengan sikap eling itu, manusia akan hidup terarah dan tidak sekedar hidup mung melik gebyar, mencari halhal yang gemerlap, tampak mewah. Manusia tidak akan tergiur terhadap wajah luar, kemewahan, dan hanya tergila-gila terhadap materi saja. Dalam hidupnya tidak akan sekedar nggedheake puluk, hanya mengejar masalah makan saja. Makan untuk hidup, bukan sebaliknya hidup untuk makan. Mereka akan selalu eling bahwa bandha titipan pangkat sampiran nyawa gadhuhan. Harta hanyalah titipan Tuhan, pangkat akan dibatasi oleh waktu, dan nyawa bagi manusia Jawa sudah dikendalikan Tuhan. Semua hal ini adalah godaan dan ujian, karenanya manusia harus bersikap eling lawan waspada. Manusia harus selalu ingat dan waspada.

Sikap eling juga akan memupuk kesadaran diri. Sadar berarti mengingat akibat yang baik dan akibat yang buruk bagi diri sendiri maupun bagi orang lain dengan iktikad menghindari akibat yang buruk dan mengusahakan akibat yang baik. Sabar berarti rasional dan tidak tergesa-gesa. Sedang teliti berarti tidak gegabah atau memakai pertimbangan yang cukup masak. Bertindak penuh pertimbangan, terencana, dimasak matang, karena itu manusia harus senantiasa sadar diri, seperti ungkapan aja bungah ing pengalem, aja susah ing panacad. Manusia harus selalu mengoreksi diri. Tidak perlu berbesar hati yang berlebihan terhadap pujian. Sebaliknya, jangan terlalu susah terhadap celaan orang lain. Kedua hal ini memang akan selalu ada. Budi pekerti eling itu akan mengarahkan manusia untuk tidak bersikap aji mumpung dalam hidupnya. Maksudnya, hidup hanya selalu menggunakan kesempatan untuk berbuat yang menguntungkan diri sendiri dan kerabat dekatnya. Melalui sikap eling, manusia akan selalu berbuat kebajikan. Jika sampai berbuat tidak baik, akan segera ingat tentang 
mati dan bertobat, sehingga berprinsip jangan sampai kinepan lawang tobat. Artinya, jangan sampai pintu tobat sudah tertutup, sudah tidak ada ampunan Tuhan lagi.

\section{Menanamkan Sikap Satriya Pinandhita}

Sikap satriya pinandhita adalah sikap manusia yang dapat menghindari tindakan-tindakan tercela. Orang seperti itu biasanya berprinsip lebih baik tidak usah hidup di dunia, daripada hidup hanya untuk melakukan perbuatan yang hina. Satriya pinandhita akan merasa malu bila melakukan tindakan yang jelek. Mereka tidak hanya merasa malu dengan sesama makhluk, tetapi juga malu kepada Tuhan dan dirinya sendiri. Oleh karena itu, sikap dan tindakannya tergolong sangat luhur. Di antara laku yang tergolong tindakan satria-pinandhita antara lain seperti wejangan Sunan Kalijaga sebagai berikut:

Menehana teken marang wong kang wuta

Menehana mangan marang wong kang luwe

Menehana busana marang wong kang wuda

Menehana ngiyup marang wong kang kodanan (Purwadi, 2004:

108).

(Berikanlah tongkat kepada orang yang buta

Berikanlah makan kepada orang yang lapar

Berikanlah pakaian kepada orang yang telanjang

Berikanlah tempat berteduh kepada orang yang kehujanan).

Tindakan demikian tergolong sangat bijaksana. Sikap satriya pinandita itu merupakan budi luhur orang Jawa. Mereka, akan berusaha menolong orang lain tanpa pamrih. Dengan jiwa yang rela dan ikhlas lahir batin, lalu memberikan tongkat kepada orang buta. Maksudnya, mau memberikan petunjuk kepada orang yang jiwanya sedang dalam kegelapan. Sikap mau memberikan makanan kepada orang yang lapar dan sandang kepada orang yang telanjang, merupakan perwujudan sikap luhur gelem dedana (mau berderma) kepada sesama. Sedangkan sikap mau memberikan payung kepada orang yang kehujanan, maksudnya mau memberi perlindungan kepada orang yang sedang mendapatkan kesedihan.

Sikap dan perilaku demikian termasuk laku yang mulia. Mereka dengan niat tulus bertindak ikhlas, berjuang, menjaga keseimbangan 
dan ketenteraman teguh janji, tanggap ing sasmita, dan berlaku adil dan bijaksana. Pendek kata, hidup dijadikan sebuah laku untuk beribadah dan manembah (mengabdi) kepada Tuhan. Hidup tidak untuk hurahura, melainkan sebagai "tirakat" yang harus diterapkan dalam hidup sehari-hari. Sikap "peduli", yaitu mau menolong tanpa ada yang menyuruh, adalah bagian sikap satriya-pinandhita.

\section{Penanaman Akhlak Mawas Diri}

Dalam pergaulan sosial kita dilarang dhemen metani alaning liyan. Maksudnya, teliti diri sendiri dahulu daripada membicarakan kejelekan orang lain. Siapa tahu diri sendiri justru lebih banyak salahnya. Bahkan jangan sampai manusia hanya dhemen ngetung becike dhewe, yang maksudnya memberi nasehat agar orang bersikap menghargai orang lain, menghargai pendapat orang lain, jangan menganggap dirinya paling unggul, paling baik atau paling benar.

Budi pekerti semacam itu akan membentuk manusia memiliki jiwa yang besar. Orang yang berjiwa besar tidak menjadi lupa daratan karena pujian dan tidak berkecil hati karena celaan. Hal ini akan mempengaruhi manusia dapat berjiwa besar, bertenggang rasa, suka memaafkan kesalahan orang lain. Dalam dirinya akan tertanam sikap bersedia mawas diri dan berani dikoreksi, akhirnya akan menjauhi watak aja dumeh dan aji mumpung.(Herusatoto, 2003: 74).

Melalui sikap aja dumeh manusia akan mudah untuk mawas diri. Mereka akan mampu berbuat tepa selira terhadap sesama, sehingga tidak berlaku daksiya atau sewenang-wenang. Sikap aji mumpung merupakan sikap pengendalian diri dari sifat-sifat serakah dan angkara murka. Apabila sedang memiliki kedudukan dia akan tetap berbuat yang sepantasnya, akan ingat bahwa hidup ini kaya dene cakra manggilingan, hidup seperti roda berputar. Orang yang mampu melakukan mawas diri, mereka akan dapat melakukan budi pekerti nandhing sarira, di mana seseorang membanding-bandingkan dirinya dengan orang lain dan mendapatkan dirinya lebih unggul, ngukur sarira, di mana seseorang mengukur orang lain dengan dirinya sendiri sebagai tolok ukur, tepa salira, di mana seseorang mau dan mampu merasakan perasaan orang lain, mawas diri, di mana seseorang mencoba memahami keadaan dirinya sejujur-jujurnya, mulat sarira, lebih dari mawas diri, di mana 
manusia menemukan identitas yang terdalam sebagai pribadi (Bratawijaya, 1988: 9).

Ungkapan giri lusi janma tan kena kinira berarti setiap manusia memiliki kelebihan dan kekurangan. Setiap manusia itu berbeda satu dengan yang lain. Karena itu, dilarang merendahkan dan atau menganggap remeh terhadap orang lain. Mencela dan mengukur orang lain merupakan perbuatan yang tidak baik. Bila seseorang dapat memastikan watak dan kekurangan orang lain dengan pengukuran dirinya berarti orang lain itu harus seperti dirinya. Hal ini tidak mungkin bisa terjadi. Penilaian secara sempurna hanyalah bisa dilakukan oleh Tuhan. Manusia diciptakan Tuhan dengan kekurangan tidak bisa untuk menilai manusia lain yang juga serba tidak sempurna.

Jika seseorang dapat ngilo githoke dhewe (berkaca pada diri sendiri), tidak akan menghina orang lain atau merendahkan orang lain, dirinya akan lebih arif dan bijaksana. Kalau orang sudah menyadari bahwa dirinya juga sama dengan orang-orang lain, yaitu mempunyai kekurangan, maka pada dirinya pasti tidak terdapat perasaan congkak dengan orang lain. Hal itu pada gilirannya pasti dapat juga menyebabkan ia berjiwa besar, bertenggang rasa, suka memaafkan kesalahan orang lain. Dalam dirinya akan tertanam sikap selalu mulat sarira hangrasa wani. Maksudnya, bersedia mawas diri dan berani dikoreksi agar dirinya mengenal bahwa dirinya telah membuat kekeliruan dalam usaha memperbaiki dirinya. Seseorang dapat berbuat jujur, tulus hati dan terbuka terhadap kritik-kritik terhadap dirinya.

\section{Penanaman Watak Ikhlas dan Sepi ing pamrih}

Sikap ikhlas mengandung ajaran agar manusia dapat mencapai kesempurnaan hidup. Manusia tidak perlu merasa takut menghadapi segala macam cobaan hidup betapapun berat penderitaannya. Manusia tidak perlu merasa takut kehilangan bila suatu waktu harus kehilangan barang milik yang disayangi. Orang yang bersikap ikhlas, akan berwatak lila legawa, kelangan ora gegetun. Artinya, bersikap ikhlas lahir batin, bahkan kehilangan sesuatu yang berharga pun tidak akan menyesal. Dalam menghadapi kenyataan yang sangat penyesalan bahkan sampai mengucapkan kata-kata yang mencoba memaki-maki Tuhan. Dalam 
segala aktivitas, seperti berjuang menegakkan hukum dan keadilan, seyogyanya juga diwarnai sikap ikhlas.

Sikap ikhlas akan membawa manusia agar bertindak sepi ing pamrih, yakni alasan dasar manusia untuk bekerja dengan motif yang bersih. Manusia yang rajin bekerja untuk dirinya dan keluarganya adalah cukup baik. Tetapi dapat dikatakan sudah memenuhi tugasnya sebagai manusia jika ia banyak berbuat kebaikan bagi orang lain tanpa pamrih. Balasan amal hanya diharapkan datang dari Tuhan semata. Bukan semata-mata mengharapkan balas budi orang lain, mentangmentang sudah menanamkan jasa.

Manusia harus bersedia mengamalkan perbuatan untuk kepentingan hidup bersama. Berbuat baik untuk orang lain bukan untuk memperoleh pujian, bukan mengharapkan sanjungan, melainkan dijalankan dengan tulus ikhlas, tanpa pamrih, yakni sikap seseorang yang membantu orang lain dengan ikhlas. Mereka sudah diniati hanya karena Tuhan semata. Tanpa ada harapan balasan dari orang yang dibantu. Uraian ini menggambarkan sikap tanpa pamrih itu suatu sikap yang hanya mengharapkan balasan dari Tuhan.

\section{Menanamkan Sifat Ngati-ati}

Dalam bergaul dengan orang lain, seseorang harus hati-hati sebab ajining dhiri seka kedaling lathi lan budi. Artinya, harga diri seseorang akan ditentukan oleh baik buruknya dalam mengeluarkan kata-kata serta cara berpikir seseorang. Pengucapan kata-kata yang tidak terkontrol misalnya sampai mengeluarkan kata-kata yang tidak senonoh, kasar, atau melukai hati orang lain, niscaya akan berakibat pada timbulnya perselisihan. Seseorang yang terlampau mudah memberikan janji, padahal jarang ditepati, termasuk orang yang tidak berhati-hati. Padahal, menurut kaidah sosial, setiap janji harus ditepati. Janji berarti hutang. Selama janji itu belum dipenuhi, berarti hutang belum lunas. Kalau orang sering ingkar akan janjinya niscaya sukarlah dia dalam mendapatkan kepercayaan dari orang lain.

Itulah sebabnya dalam tutur kata harus senantiasa diatur, dipikirkan, dan atau omong sing maton, aja mung waton omong. Berkatalah yang dilandasi pikiran, jangan asal bicara. Dia harus dapat memperhatikan tentang apa yang dia bicarakan, dalam forum apa dia 
berbicara, dalam suasana bagaimana, dan dihadapan siapa dia berbicara. Segala gerak dan tindakan harus selalu empan papan (ingat situasi dan kondisi) dan tidak grusa-grusu waton kesusu (bertindak gusar dan terburu-buru). Orang Jawa berprinsip dalam menjalankan sesuatu lebih baik alon-alon waton klakon. Maksudnya dalam melaksanakan pekerjaan sebaiknya dilakukan dengan penuh perencanaan, perhitungan, tak perlu terburu-buru, asalkan sampai pada tujuan.

Untuk mencapai sesuatu, perlu laku, perlu langkah, dan tatacara yang terarah. Perlu rencana dan proses, dan jangan ambil jalan pintas. Misalnya, jika kita bercita-cita mencapai gelar kesarjanaan, hendaklah kita suka belajar secara teratur. Kita harus mau mulai dari tingkat yang paling bawah, kemudian meningkat terus setingkat demi setingkat sehingga belajar di semua kelas sekolah dasar, sekolah menengah tingkat pertama, sekolah menengah tingkat atas, dan semua tingkat di perguruan tinggi pernah kita alami. Kecuali itu dalam proses usaha mencapai gelar kesarjanaan tadi janganlah kita membeli ijazah palsu atau melakukan penyuapan supaya naik kelas atau tingkat tanpa belajar dengan sungguh-sungguh. Jika kita bercita-cita menjadi orang yang berpangkat tinggi, janganlah cita-cita itu kita capai dengan cara-cara yang menyimpang dari peraturan misalnya dengan menyuap petugas dan sebagainya. Sebaliknya, semua hal itu kita capai dengan jalan bekerja secara jujur, tekun, kreatif, produktif, dan sebagainya.

Manusia boleh saja bersikap gigih, tekun, dan sabar di dalam usaha mencapai cita-cita; tidak lekas putus asa, tidak lekas patah semangat tidak cepat belok haluan. Menetapkan cita-cita adalah hal yang mudah, tetapi berikhtiar agar apa yang dicita-citakan itu menjadi kenyataan secara wajar adalah hal yang sulit. Meskipun demikian, orang haruslah senantiasa berusaha agar apa yang diidamkan itu dapat tercapai. Kendati waktu yang diperlukan untuk mencapai cita-cita itu sangat banyak, harus maju terus, bertekad pantang mundur sampai apa yang dicita-citakan itu betul-betul dapat tercapai. Penggarapan sesuatu tugas, yang penting bukannya cepat atau lambatnya tugas itu diselesaikan, melainkan lebih diutamakan ketepatan pengerjaannya sesuai dengan sasaran yang ditentukan. Kalau dapat diselesaikan dengan cepat tetapi hasilnya tidak kena dengan sasaran yang akan dituju, maka hal itu lalu dikatakan dengan kebat kliwat (cepat tetapi 
tidak tepat). dalam suasana yang wajar. Ketidakwajaran di dalam menempuh hidup dapat mendorong orang akan bersikap dan berbuat yang bukan-bukan. Jika ini diindahkan maka tidak akan ada manipulasi, korupsi, penyelewengan serta penyalahgunaan wewenang. Manusia akan merasa puas dan nikmat serta bersyukur dengan berbagai hal yang dapat dicapai. Mereka akan menyadari bahwa segala sesuatu telah diatur, digariskan. Siapa tahu takdir Tuhan itu merupakan jalan terbaik buat manusia.

\section{Menanamkan Watak Nrima}

Watak nrima, hanya akan terpatri pada jiwa seseorang apabila mereka mudah bersyukur. Kesadaran terhadap nikmat yang diterima, disyukuri sebagai karunia Tuhan. Dengan cara ini, manusia akan selalu berprasangka baik kepada Tuhan. Mungkin, apa yang selama ini diraih, memang jalan terbaik yang ditunjukkan Tuhan. Karena itu, lalu tidak harus misuh-misuh atau mengumpat kepada orang lain apalagi lagi kepada Tuhan.

Sikap nrima, tidak berarti harus diam saja, pasif dan menunggu bola tanpa usaha. Nrima bukan prinsip hidup fatalistik. Namun, dalam segala upaya kehidupan harus selalu berusaha keras, lalu bersandarkan ke hubungan vertikal. Kalau sudah berupaya sekuat tenaga, Tuhan akan mengubah nasib atau belum, semuanya hak Tuhan.

\section{Penanaman Watak Pasrah}

Sikap pasrah terhadap takdir termasuk pandangan ke arah sikap teosentris, yaitu sikap yang berdasarkan pandangan, bahwa Tuhan adalah pusat kehidupan. Seseorang yang teosentris memandang Tuhan sebagai pihak yang memimpin hidupnya. Semua tingkahlakunya disesuaikan dengan kehendak Tuhan. Seseorang yang teosentris selalu menerima nasibnya dengan senang hati, sebab ia berpendapat bahwa nasib baik maupun nasib buruk yang diterimanya berasal dari Tuhan dan bahwa Tuhan tentu selalu berkehendak baik. Manusia janganlah bertindak nggege mangsa. Maksudnya mendahului kehendak Tuhan. Jangan berbuat macam-macam yang bertentangan dengan kehendak Tuhan. Serahkanlah segala sesuatu kepada Sang Pencipta. Karena itu 
kalau memiliki cita-cita, jangan sarnpai menempuh jalan pintas. Tunggu jika Tuhan sudah menghendaki, semuanya akan mudah dan ada jalan. Jika belum pasti rintangan yang akan menimpa. Sikap pasrah, harus disertai rasa sumarah kepada Tuhan. Jika manusia telah berjuang matimatian, ternyata Tuhan menghendaki lain, manusia harus juga menyadarinya. Dengan dernikian, hubungan dengan Tuhan akan tetap baik dan tidak selalu curiga. Misalkan, bila sedang menunggu orang sakit kritis, tentu semuanya harus dikembalikan kepada kehendak Tuhan. Jika terpaksa pasien itu harus diambil oleh Sang Pencipta, manusia tidak bisa berbuat apa-apa, kecuali hanya bersikap pasrah sumarah, bahwa nyawa itu hanyalah gadhuhan (pinjaman) dari Tuhan. Dalam kohteks budaya Jawa, dikenal ungkapan: dikuncenana, dirantea, didhadhunga, yen wis dikersaake bakal bali marang asale. Maksudnya, meskipun nyawa itu dikunci rapat, diberi tali dengan rantai, diikat dengan dadung yang kuat, kalau sudah dikehendaki, akan kembali kepada asalnya, Tuhan.

Pada tingkat pasrah sumarah, akan terkandung pengertian bahwa 'manungsa mung saderma ngglakoni' (manusia memang hanya melaksanakan yang sudah ditakdirkan). Manusia hanya bisa berupaya, sedangkan kepastian di tangan Tuhan. Hal ini juga berlaku pada usahausaha yang sifatnya masih terkait dengan kehidupan di dunia. Misalkan, kita sedang mengikuti lomba apapun. Manusia hanya wajib berusaha secara halal, Tuhan yang akan menentukan. Kita tidak perlu mengumpat, teman yang lain sudah terlalu cepat lulusnya, sudah mendapat pekerjaan, sementara kita masih harus berjuang, Kita juga tidak perlu iri kepada teman yang berhasil memenangkan lomba, sementara kita kalah. Mungkin, semua itu sudah ditakdirkan, kapan kita harus selesai membuat tesis, harus lulus, harus bekerja, harus menang dalam lomba, dan sebagainya.

\section{Model Penanaman Budi Pekerti Jawa}

\section{Tahap Penanaman Budi Pekerti Jawa}

Dalam masyarakat Jawa, sejak kecil anak-anak atau bahkan sebelum lahir telah dididik tentang perbuatan baik dan buruk. Pengenalan sikap dan watak baik buruk ini merupakan rentetan upaya agar anak-anak mencerna dan mengamalkan budi pekerti luhur. Budi 
pekerti adalah sebuah konsep kejiwaan. Budi pekerti harus diterapkan dalam kehidupan. Penyampaian budi pekerti, ada yang melalui katakata, contoh, gerakan, dan tindakan nyata. Penyampaian budi pekerti dalam masyarakat sebenarnya mengikuti tataran hidup yang dilalui oleh manusia, seperti yang dijelaskan oleh Muhsinun sebagai berikut:

Pertama, masa bayi dalam kandungan dan masa kanak-kanak. Pada saat ini budi pekerti mulai ditanamkan cukup hati-hati. Cara penyampaian berupa wulangan dari pihak orang tua kepada anak. Dasar utama budi pekerti yang disampaikan adalah sopan santun, tatakrama, sikap hormat-menghormati, saling menghargai, cara berbicara, cara makan, unggah-ungguh dan sebagainya. Penerapan budi pekerti pada masa anak-anak ini masih sangat sederhana. Bahkan pada saat itu hanya disampaikan beberapa aturan baik berupa larangan maupun anjuran. Misalkan saja, orang tua akan memberikan piwulang kepada anaknya apabila diberi sesuatu oleh orang lain harus mengucapkan: "Matur nuwun".

Ucapan matur nuwun, sebenarnya hanya singkat tetapi kandungan budi pekertinya sangat dalam. Matur nuwun adalah penghargaan kepada orang lain yang luar biasa. Ucapan terirna kasih juga sekaligus rnengindikasikan hubungan manusia kepada sesama dan kepada Tuhan atas pemberian sesuatu itu. Setelah itu, anak-anak diberi ajaran pendek lagi ketika bertamu harus: "Kula nuwun" atau assalamu'alaikum dan ketika pulang harus mengucapkan "pamit"'. Baik kula nuwun, assalamu'alaikum maupun pamit sebenamya merupakan budi pekerti yang harus dibiasakan sampai rnanusia berusia dewasa bahkan sampai tua.

Pada masa kanak-kanak, penyampaian budi pekerti dengan model larangan dan ora ilok masih dianggap perlu. Karena, pada rnasa itu anak-anak diharapkan patuh. Misalkan saja, ora oleh ngidoni sumur mundhak suwing, artinya tidak boleh meludahi sumur nanti bibirnya sumbing. Anak mungkin juga dilarang menduduki bantal agar tak terkena penyakit wudun (bisul), anak dilarang makan sambil berdiri, anak dilarang ini-itu dan seterusnya, dengan maksud agar rnereka benar-benar patuh terhadap budi pekerti.

Kedua, pada saat menginjak remaja budi pekerti perlu disampaikan dalam bentuk wejangan. Pada masa remaja budi pekerti 
yang diberikan tidak terbatas pada hal-hal yang sederhana dan hubungan sosial semata, melainkan telah terkait dengan masalahmasalah Ketuhanan. Bagaimana manusia harus berhubungan dengan makhluk-makhluk gaib, mulai ditanamkan. Di samping itu, konsepkonsep budi pekerti yang mengarah ke hubungan laki-laki - perempuan, bagaimana manusia harus bekerja, bagaimana manusia harus manembah, dan sebagainya mulai ditebarkan. Misalkan, anak remaja diajari tentang konsep bekerja yang alon-alon waton kelakon. Maksudnya, bekerja dengan pelan-pelan yang penting terlaksana dengan baik. Pelan-pelan berarti juga tidak perlu ngaya atau ngrangsang, sehingga segala sesuatunya dilakukan menurut waton (aturan) dan pedoman. Bekerja dengan model diseperti ini benar-benar harus direncanakan, bukan sebaliknya alon-alon asal kelakon, diartikan dengan menjalankan pekerjaan dengan asal-asalan.

Ketiga, pada usia dewasa, budi pekerti mengarah pada konsepkonsep moralitas hidup. Upaya-upaya hidup seperti mencari bekal yang akan dijadikan sandaran hidup di akhirat kelak, mulai ditanamkan. Wujud wedharan tidak harus kentara atau kasat mata, melainkan berupa simbol-simbol dan sasmita. Misalkan saja, pada usia dewasa diberi wedharan tentang budi pekerti luhur: "mikul dhuwur mendhem jero" yang biasa disimbolkan ketika ada upacara susuhan/brobosan pada pemberangkatan jenazah. Mikul dhuwur berarti menjunjung tinggi jasa orang tua dan menjunjung tinggi harkat dan martabat serta kehormatan orang tua atau leluhur dengan sepenuh hati. Mendhem jero berarti menutup lubang-lubang atau kesalahan orang tua atau leluhurnya. Menutup rapat-rapat segala aib, kekurangan dan kelemahan orang tua agar jangan diketahui oleh masyarakat umum. Itulah sebabnya, sikap tersebut selalu diabadikan agar seorang anak lebih tahu diri. Hal ini berarti seorang anak yang selalu mengungkit-ungkit kesalahan orang tua atau bahkan mempersoalkan warisan, kurang dibenarkan. Anak yang demikian dalam masyarakat Jawa dianggap kurang tata atau kurang tahu aturan. 


\section{Model Penanaman Budi Pekerti}

\section{a. Model Demokrasi}

Internalisasi budi pekerti sesungguhnya merupakan wahana penanaman nilai, yang di dalarnnya tidak sekedar memindahkan nilai, melainkan melalui proses penghayatan nilai. Secara tradisional, penanaman nilai menjadi tanggung jawab orang tua dan lembaga. Sayangnya, kedua pilar yang mestinya lebih bertanggung jawab terhadap internalisasi nilai budi pekerti ini, belum berusaha secara optimal. Padahal, generasi penerus selalu mengharapkan figur-figur yang bisa dijadikan petunjuk arah, supaya tidak tersesat. Generasi penerus membutuhkan figur-figur orang tua dan masyarakat yang dapat diacu dalam segala aspek kehidupan.

Model demokrasi menekankan pencarian secara bebas dan penghayatan nilai-nilai hidup dengan langsung melibatkan anak untuk menemukan nilai tersebut dengan melibatkan pendampingan dari orang tua. Anak diberi kesempatan untuk memberikan tanggapan, pendapat, dan penilaian terhadap nilai yang ditemukan. Tahap demi tahap anak diarahkan untuk menata jalan pikiran, cara berbicara, dan sikap hidupnya. Model ini digunakan untuk menanamkan nilai-nilai keterbukaan, kejujuran, penghargaan pada pendapat orang lain, sportivitas, kerendahan hati dan toleransi.

Internalisasi budi pekerti Jawa di masyarakat luas ini rupanya yang menjadi persoalan. Jika penyemaian budi pekerti dilakukan dengan model penataran P4 seperti pada masa Orde Baru, kiranya masyarakat sudah jenuh. Untuk itu, perlu strategi baru yang segar dan dinamis. Maksudnya, jangan sampai terjadi internalisasi budi pekerti model "cekokan" seperti masa lalu. Masyarakat telah belajar demokrasi, karenanya penyemaian budi pekerti pun seharusnya mengikuti irama demokrasi. Artinya, bagaimana upaya pemerhati budi pekerti agar menciptakan sistem sosialisasi dan internalisasi yang sehat, menyenangkan, tak memaksa, tetapi mengena.

Itulah sebabnya, internalisasi budi pekerti perlu disampaikan dalam suasana yang kondusif dan tidak memasung kreativitas penerimanya. Salah satu pendekatan yang bisa ditempuh, antara lain melalui pendidikan kritis. Maksudnya, proses penanaman budi pekerti sebagai upaya sadar untuk mempersiapkan generasi penerus, termasuk 
anak yang kritis. Generasi penerima harus diberi ruang gerak untuk berpikir kritis terhadap tawaran nilai budi pekerti. Bahkan, sangat mungkin budi pekerti yang ditawarkan tidak harus seragam di antara individu atau kelompok tertentu sehingga memahami prinsip relativisme. Budi pekerti merupakan usaha memasyarakatkan hak asasi manusia serta perlawanan terhadap ketidakadilan agar terbentuk suatu hubungan sosial yang adil dan bebas dari kekerasan.

Konsepsi demikian menggambarkan bahwa internalisasi budi pekerti diperlukan kontak sosial yang tepat dan dinamis. Maksudnya, tidak lagi ada "pemaksaan" kehendak, namun perlu dikembangkan bargaining (tawar-menawar) nilai budi pekerti antara kedua belah pihak. Akhirnya, internalisasi dan penanaman budi pekerti perlu disampaikan dalam bentuk rangsangan-rangsangan, biarlah pihak penerima mencoba memahami dirinya sendiri. Biarlah mereka mengolah dan menerapkan budi pekerti secara adapdif. Penanaman budi pekerti melalui wawasan demokratisasi akan menuju pada pembaharuan kultur dan norma keberadaban. Dalam kaitan ini, internalisasi budi pekerti ditempuh melalui interaksi secara wajar.

\section{b. Model Keteladanan}

Segala sesuatu yang dilakukan oleh orang tua akan ditiru oleh anak-anak. Apa yang dikatakan oleh orang tua akan terekam dan kemudian akan dimunculkan kembali oleh anak. Proses pembentukan budi pekerti anak dimulai dengan melihat orang yang diteladani. Oleh karena itu, orang tua harus bertutur kata dan berperilaku yang terpuji sebab ia menjadi tokoh idola bagi anaknya. Keselarasan dan kesatuan kata dan perbuatan orang tua sangat berarti bagi seorang anak. Untuk itu, orang tua dituntut ketulusan, keteguhan dan konsisten dalam hidup.

Faktor keteladanan, jelas fenomena penting yang sulit ditawartawar dalam menginternalisasikan budi pekerti. Hal ini sejalan dengan gagasan bahwa ada tiga pendekatan internalisasi budi pekerti, yaitu pendekatan kultural pendekatan manajemen dan pendekatan keteladanan. Ketiga pendekatan ini saling melengkapi satu sama lain. Pendekatan pertama mendasarkan pada suatu proses humanistis, pendekatan kedua suatu proses yang tertata rapi, dan pendekatan ke 
tiga berdasarkan asumsi bahwa hidup membutuhkan "bintang-bintang pedoman" yang bisa dijadikan petunjuk arah, supaya generasi penerus tidak tersesat dan kehilangan arah. Pendekatan ke tiga tersebut mengisyaratkan bahwa faktor keteladanan selayaknya menjadi pertimbangan tersendiri dalam internalisasi budi pekerti.

\section{c. Model Pencarian Bersama}

Model ini menekankan pencarian nilai bersama-sama antara anak dengan orang tua dengan cara mendiskusikan soal-soal yang aktual di masyarakat. Dengan model ini diharapkan bisa menumbuhkan cara berpikir logis, sistematis, analitis dan argumentatif untuk mengambil nilai-nilai yang diolah bersama. Melalui model ini pulaanak diajak untuk mencari dan menemukan tema yang sedang berkembang dan menjadi perhatian bersama. Dengan menemukan permasalahan, mengkritisi dan mengolahnya, anak diharapkan dapat mengambil nilai yang baik, kemudian dapat menerapkan ke dalam kehidupan sehari-hari. Anak juga diajak untuk kritis mengolah sebab akibat dari permasalahan yang muncul dan tidak boleh terburu-buru mengambil kesimpulan. Di samping itu, anak juga diajak untuk melihat realita sehingga segalanya tidak harus dihukumi hitam putih.

\section{d. Memasang Tokoh Wayang}

Cerita-cerita dan tokoh wayang ternyata bermanfaat untuk mendidik budi pekerti. Hal ini dilakukan oleh Muhsinun kepada keluarganya. Dia memasang gambar wayang ternyata bukan sekedar hiasan dinding saja, tetapi mempunyai tujuan yang sangat luhur yakni sebagai pendidikan budi pekerti bagi keluarganya. Tokoh-tokoh wayang dapat digunakan sebagai media penanaman budi pekerti. Tokoh wayang tersebut merupakan figur atau gambaran seseorang dalam kehidupan sehari-hari. Misalkan Semar adalah lambang karsa atau kemauan yang agung yang baik, dan segala hal yang luhur. Semar, dari bahasa Arab simaar artinya paku. Maksudnya, kebenaran yang didukung oleh Semar sifatnya kuat dan kokoh seperti paku. Semar merupakan lambang ibadat, yaitu dengan menyebut asma Allah. Dalam wawasan kosmologi Jawa Semar memang menggambarkan pengendali nafsu kebaikan dan 
kebajikan. Sedangkan pengendali nafsu keangkaramurkaan adalah Togog.

\section{e. Penggunaan Bahasa Jawa Madya dan Krama Dalam Keluarga}

Struktur dalam bahasa Jawa mengenal beberapa tingkatan, dan masing-masing tingkatan penerapan dan penggunaannya harus tepat. Misalnya tingkatan ngoko untuk tingkatan usia yang sepadan atau dari yang tua kepada yang muda, tingkatan madya adalah dari yang muda kepada yang lebih tua, demikian pula tingkatan krama digunakan dari yang muda kepada yang lebih tua atau pun untuk orang-orang yang dihormati. Dengan adanya tingkatan-tingkatan yang terdapat dalam bahasa Jawa inilah justru menunjukan secara langsung unggah-ungguh dan tatakrama dalam budaya Jawa. Misalnya kata makan, ngokonya mangan, nedha (madya), dhahar (krama). Kata tidur ngokonya turu, tilem (madya) sare (krama). Dengan demikian, orang tua dalam berinteraksi dalam keluarga secara langsung membimbing dan mengarahkan anak-anaknya dalam pengunaan bahasa Jawa madya dan krama secara tepat. Hal ini bila dibiasakan dalam keluarga akan dapat membentuk kepribadian anggota keluarga yang mengenal unggah unguh, tata krama dan sopan santun dalam kehidupan bermasyarakat, seperti yang dilakukan oleh tiga keluarga di Desa Bonjokmangir, yaitu keluarga Aris, Sarino dan Muhsinun.

Bila kita perhatikan dalam masyarakat Jawa, penggunaan bahasa Jawa madya dan karma dalam keluarga-keluarga Jawa sudah jarang digunakan sebagai alat komunikasi dalam keluarga. Kalau toh masih ada jumlahnya sedikit sekali, tidak sebanding dengan banyaknya jumlah keluarga-keluarga dalam masyarakat Jawa. Ada beberapa faktor yang menyebabkan hal tersebut di antaranya lemahnya penguasaan dan pemahaman terhadap bahasa Jawa akibat kurang adanya pembelajaran bahasa Jawa secara dini pada ranah keluarga, ada kecenderungan orang tua sekarang justru lebih bangga jika anaknya menggunakan bahasa Indonesia untuk percakapan sehari-hari daripada menggunakan bahas Jawa. Kecenderungan ini sebenarnya juga dipicu oleh ketidakmampuan orang tua dalam bertutur Jawa. Di samping itu, munculnya rasa nyaman menggunakan bahasa Indonesia daripada bahasa Jawa, untuk 
menghindari rasa salah dan rasa kurang sopan. Hal ini menimbulkan pergeseran sikap terhadap pemakaian bahasa Jawa. Perilaku ini muncul akibat ketidakpahaman terhadap tingkat tutur bahasa Jawa.

\section{Penutup}

Keluarga adalah tempat ideal penyemaian budi pekerti. Di dalam keluarga anak akan banyak belajar secara praktis melalui berlatih dan meniru budi pekerti orang-orang yang ada di sekitarnya, utamanya adalah orang tua. Seperti halnya upaya yang dilakukan oleh tiga keluarga Jawa di Bonjokmangir dalam menanamkan nilai-nilai budi pekerti Jawa dalam keluarga bisa disimpulkan sebagai berikut:

Tiga keluarga Jawa di Bonjokmangir menganggap penting untuk melakukan internalisasi nilai-nilai budi pekerti dalam keluarganya demi eksistensi dan keberlangsungan keluarga tetap menjadi keluarga yang baik dan berkepribadian. Oleh karena itu ditanamkanlah nilai-nilai budi pekerti dalam keluarga sejak dini sebagai bekal hidup dalam bermasyarakat. Nilai-nilai budi pekerti yang ditanamkan pada ketiga anggota keluarga Jawa yaitu prinsip hormat, menanamkan kerukunan hidup, menanamkan sifat jujur, akhlak mawas diri, penanaman watak ikhlas dan sepi ing pamrih, membentuk watak eling, membentuk watak satriya pinandhita, pembentukan akhlak sopan santun, membentuk sifat ngati-ati, penanaman watak nrima, dan penanaman watak pasrah. Semua nilai-nilai budi pekerti ini ditanamkan dalam keluarga agar kehiupan keluarganya selamat.

Bila keluarga memegang prinsip hormat, saling menghormati antara anggota keluarga dan diperluas pada anggota masyarakat, implikasinya adalah saling menghargai dan saling menyayangi. Dengan demikian terwujudlah keluarga yang damai. Demikian pula nilai-nilai budi pekerti yang lain diharapkan bisa dihayati oleh semua anggota keluarga dan mengkristal dalam jiwanya sehingga menjadi bagian dalam hidupnya. Bila sudah mencapai tingkatan seperti itu dalam pengamalannya pun secara mudah akan berjalan dengan sendirinya.

Dalam penanaman nilai-nilai budi pekerti melalui tahapan usia yang dilalui oleh manusia yaitu, Pertama, masa bayi dalam kandungan dan masa kanak-kanak. Pada saat ini budi pekerti mulai ditanamkan hal-hal yang masih sederhana. Cara penyampaian berupa wulangan 
dari pihak orang tua kepada anak. Dasar utama budi pekerti yang disampaikan adalah sopan santun, tatakrama, sikap hormatmenghormati, saling menghargai, cara berbicara, cara makan, unggahungguh dan sebagainya. Kedua, pada saat menginjak remaja budi pekerti perlu disampaikan dalam bentuk wejangan. Pada masa remaja budi pekerti yang diberikan sudah mulai kompleks, termasuk masalah Ketuhanan, pekerjaan, hubungan antara laki-laki dan perempuan, bagaimana manusia harus menyembah dan sebagainya. Ketiga, pada usia dewasa, budi pekerti mengarah pada konsep-konsep moralitas hidup. Upaya-upaya hidup seperti mencari bekal yang akan dijadikan sandaran hidup di akhirat kelak, mulai ditanamkan. Wujud wedharan tidak harus kentara atau kasat mata, melainkan berupa simbol-simbol dan sasmita. Misalkan saja, pada usia dewasa diberi wedharan tentang budi pekerti luhur: "mikul dhuwur mendhem jero" yang biasa disimbolkan ketika ada upacara susuhan/brobosan pada pelepasan jenazah.

Adapun model-model yang digunakan dalam rangka internalisasi nilai-nilai budi pekerti dalam keluarga adalah model demokrasi, model keteladanan, model pencarian bersama, model pemasangan tokoh wayang dan penggunaan bahasa Jawa madya dan karma dalam keluarga.[] 


\section{DAFTAR PUSTAKA}

Bratawijaya, Thomas Wiyasa. 1988. Upacara Tradisional Masyarakat Jawa. Jakarta: Sinar Harapan

Handayani, Christina S. Novianto. 2004. Kuasa Wanita Jawa. Yogyakarta: LKiS.

Herusatoto. 2003. Simbolisme dalam Budaya Jawa. Yogyakarta: Hanindita Graha Widya. 2003

Koentjaraningrat. 1984. Kebudayaan Jawa. Jakarta: Balai Pustaka

Prasetiyo dan Mugiyarto. 2003. Petuah dan Kisah Bijak Budaya Jawa. Yogyakarta: Hanindita Graha Widya

Purwadi. 2004. Dakwah Sunan Kalijaga, Yogyakarta: Pustaka Pelajar

Simon, Hasanu. 2008. Misteri Syekh Siti Jenar. Yogyakarta: Pustaka Pelajar.

Supadjar, Damarjati. 1985. 'Etika dan Tatakra Jawa: Dahulu dan Masa Kini' dalam Soedarsono (Ed.) Keadaan dan Perkembangan Bahasa, Sastra, Etika, Tatakrama dan Seni Pertunjukan Jawa, Bali, dan Sunda. Yogyakarta: Depdikbud 